\title{
Body-Part Morphemes in Matis (Panoan)
}

\author{
Raphael Augusto Oliveira Barbosa \\ University of São Paulo (USP), Brazil
}

\begin{abstract}
Grammatical and pragmatic aspects of body-part constructions represent relevant theme for typological and functional researches in the Amerindian languages. Despite the researches on body-part morphemes in the Matis language since the beginning of the $21 \mathrm{st}$ century, studies have been restricted to brief inventories and to the description of isolated clauses. In the present article, I describe the
\end{abstract}

$\S$ I would like to thank Dejan Matić, for his valuable guidance and support in an earlier version of this article; Bushe Matis, for his helpful assistance on the body-part terms; the two anonymous reviewers from the Journal of Universal Language (JUL); and the São Paulo Research Foundation (FAPESP) for the research grant 2019/09686-9. All the remaining mistakes in the proposed analysis are my responsibility.

Raphael Augusto Oliveira Barbosa

Postdoctoral Researcher, Department of Classical and Vernacular Letters, University of São Paulo (USP), Brazil

Email: raphael.aob@gmail.com

Received 28 July, 2020; Revised 23 September, 2020; Accepted 9 March, 2021

Copyright (C) 2021 Language Research Institute, Sejong University Journal of Universal Language is an Open Access Journal. All articles are distributed online under the terms of the Creative Commons Attribution Non-Commercial License (http://creativecommons.org/licenses/by-nc/3.0) which permits unrestricted non-commercial use, distribution, and reproduction in any medium, provided the original work is properly cited. 
extended body-part inventory and the typological aspects of the Matis body-part morphemes. In doing so, it is proposed the systemic functional analysis of its lexicogrammatical features and pragmatic properties in contextual constructions of narratives collected in fieldwork. The findings of this analysis shows that, in clause chaining constructions, the functional relation of body-part morphemes and its possessor is established on referential progression by means of the participant agreement in the switch-reference system. Moreover, prefixed verbs can be preceded by the correspondent body-part nouns to convey focus expression, and polysyllabic nouns can also indicate topic function when structured at the beginning of the clause. The systemic functional analysis of the body-part morphemes through textual data seek to collaborate on the knowledge of the interaction between lexicogrammatical and pragmatic systems in the Matis language.

Keywords: body-part typology, reduplication, switch-reference, metaphor, information structure, systemic functional grammar, Matis narratives, Panoan family

\section{Introduction}

Matis language has 30 body-part prefixes, which are attached to adjectives of colour and mainly verbs of action, to indicate bodily references of absolutive arguments. Studies of the Matis body-part morphemes have been restricted to brief inventories and to the description of isolated clauses. In the present article, I describe the extended body-part inventory and the typological aspects of these morphemes in the Matis language. With this in view, it is proposed an innovative systemic functional analysis of its lexicogrammatical features and pragmatic properties in clause-chaining constructions of narratives collected in fieldwork.

Matis people live in the Javari Valley Indigenous Territory (in three 
villages called Paraiso, Tawaya and Kuraya), and in the town of Atalaia do Norte (home to several indigenous families from the Javari Valley), west of the state of Amazonas, Brazil. The language is spoken in the villages and also in the city, where the people communicate in their native language, except in commercial and educational contexts in which Portuguese language is used. According to Social-Environmental Institute (ISA 2014), Matis population was about 457 individuals in 2014.

This language belongs to Panoan family, which has approximately 30 languages, and roughly 20 of these languages are still spoken today in the Amazon western regions of Brazil, Peru and Bolivia. Several scholars have refined the relations of the Panoan family and, according to Ribeiro (2006), from the mid-twentieth century, more systematic classifications and comparative studies expanded the knowledge about the historical development of the languages as well as the internal structure of the linguistic family. For example, preliminary internal classifications, based on linguistic criteria, were performed by Lanes (2005), Ribeiro (2006) and Fleck (2013).

The classification proposed by Lanes (2005) presents the Matis language along with the Matses language in the same branch, which is described by the author as the furthest group from other Panoan languages. The study presented by Ribeiro (2006) contains the classification of the Matis language in the group called IV-1, which is composed of the languages Matses, Kapishto and Kulina as well. The classification proposed by Fleck (2013) presents the Mayoruna branch that contains the languages Matis, Matses, Kulina, Demushbo, Korubo, Mayoruna of the Jandiatuba River, Mayoruna of the Amazon River and Mayoruna of Tabatinga.

The next session describes the materials and method procedures of the study, then the systemic description of the body-part morphemes. 
Firstly, I describe the inventory of 30 body-part prefixes along with the morphological forms and meanings; the interaction of prefixation and verbal reduplication; and the analysis of the syntactic tracking of the prefixes in switch-reference system. ${ }^{1}$ After that, it is presented the semantic extension from basic prefix meanings, and the pragmatic information related to the body-part morphemes. Finally, the study is complemented by the conclusion and the bibliographical references.

\subsection{Materials and Method}

Linguistic and anthropological knowledge about the Matis language and people, contacted in the mid-1970s, developed from the beginning of the 21 st century, with the accomplishment of descriptive researches and some comparative accounts. For instance, anthropological and ethnographic aspects of Matis people were studied chiefly by Arisi (2007, 2011, 2012, 2017). Furthermore, grammatical aspects of the language were described by the linguists Ferreira R. (2001, 2005, 2012, 2017) and Ferreira V. (2000, 2005), and some comparative studies were done by Barbosa $(2012,2014,2018){ }^{2}$

In the present paper, the analysis of the body-part morphemes in the Matis language is presented on the basis of primary data, with examples primarily coming from narratives collected and transcribed with native speakers, and also a few of them from the study of Ferreira R. (2005). With this in view, I describe the systemic functional aspects of the Matis body-part morphemes and propose the analysis of its

1 The opposing exclusive pair of encoding pattern glossed as ID 'identity' and NONID 'non-identity' is used throughout this paper, since this terminology capture the multi-layered connections of this phenomenon, in contrast to the traditional terms 'same subject' and 'different subject' (van Gijn 2016).

2 Matis grammatical systems are currently been described, such as morphosyntactic alignment (Barbosa 2020), switch-reference (Barbosa n.d.a), and also a study on the consonantal system (Barbosa et al. n.d.b.). 
lexicogrammatical system in order to find out semantic and pragmatic functions in clause-chaining constructions of narratives collected in fieldwork.

Body-part morphemes have been described in various languages of the Panoan family, both in the form of nouns and monosyllabic prefixes, with about 20 to 30 prefixes in each language. Studies already published thus far describe the inventory of these morphemes and its grammatical properties, as well as some discussion on the description as nominal incorporation or prefixation (Fleck 2006, Ribeiro \& Cândido 2008, Zariquiey \& Fleck 2012, Rodriguez 2017).

Regarding the synchronic status of the Matis body-part morphemes, I analyze the prefixes of this language as independent items, that is, these monosyllabic morphemes are not synchronic variations of the polysyllabic nominal items (as presented in Loos (1999) for other Panoan languages). In this sense, the lexis of the Matis language has two sets of morphemes that refer to body parts; monosyllabic morphemes, which in the form of prefixes are attached to lexical bases, and polysyllabic nouns, which are used with discursive purposes.

The morphological structure of the Matis language is characterized as synthetic-agglutinative, and therefore in the present analysis I consider the morpheme as the minimum unit. Thus, unlike the morpheme-and-process approach, I take the methodological procedure known as morpheme-and-arrangement, considering the descriptive principles presented by Aikhenvald (2007). Regarding the analysis of the systemic and communicative functions of the body-part morphemes, I follow the theoretical notions proposed by Lakoff \& Johnson (1980), Krifka (2007), Halliday \& Matthiessen (2014), and Matić et al. (2014). 


\section{Grammatical Description of Body Parts in Matis}

The brief typological profile of the Matis grammar is as follows: the order of constituents in main clauses is flexible, with a tendency to $\mathrm{S}$ (ubject)O(bject)V(erb)/SV configuration, and verbs in subordinate clauses must come last. Word order in possessive constructions is quite rigid, which means possessors, marked in the genitive case, are always followed by possessees. The morphology is essentialy structured as agglutinative and synthetic, in which verbal roots receive postpositions, and also prefixes referring to body parts.

The grammatical relations of the Matis language are basically characterized by ergative-absolutive alignment. As with syntactic level, the morphology of nominal items and singular pronouns follows the ergative-absolutive pattern, with the exception of the first-person plural which follows the direct pattern, and the second-person plural, the nominative-acusative pattern. Adverbial items receive suffixes for participant agreement to the subject argument of the clause. Finally, the switch-reference system indicates the alternation and coreference of arguments, as well as logical-temporal relations and participant agreement between clauses.

The following subsections describe the body-part morphemes in the Matis language, according to the theoretical principles of the systemic functional grammar presented by Halliday \& Matthiessen (2014). With this in view, it is presented the analysis about the interaction of the body-part system with other lexicogrammatical systems, like reduplication and switch-reference. In doing so, the description of the narrative data is presented as language functioning in context, and the textual resources, as an instantiation of the body-part system. 


\subsection{Morphological Form of Body-Part Morphemes}

Body-part meanings in the Matis language are conveyed by monosyllabic prefixes, which are attached to colour adjectives and, especially, action verbs. In addition to these bound morphemes, the vocabulary of this language also has nominal morphemes, that besides conveying the same meaning of the prefixes, express specific parts of the body. The Table 1 presents the forms and meanings of the bodypart prefixes and nouns (formed by two or more syllables-usually beginning with the same prefix form).

Table 1. Bound and Free Morphemes Relating to Body Parts in the Matis Language

\begin{tabular}{|c|c|c|}
\hline Prefixes & Nouns & Meanings \\
\hline \multirow{2}{*}{ an- } & ana & tongue \\
\hline & ana rişan/riş $\beta \mathrm{u}$ & tongue tip \\
\hline \multirow{5}{*}{$\beta \dot{\mathbf{t}}-$} & $\beta$ imanan & face, forehead \\
\hline & 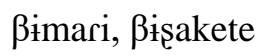 & eyelash \\
\hline & $\beta$ iru & eye \\
\hline & Biru kasuku & eyelid \\
\hline & Biru kuisamawi & eyebrow \\
\hline in- & ina & penis, tail \\
\hline \multirow{2}{*}{ ik- } & ik $\beta$ ik & lip \\
\hline & ¡kşak & mouth \\
\hline \multirow{3}{*}{ ka- } & kaspan & upper back \\
\hline & kaşuku & back \\
\hline & kasuku wispo & lumbar (lower back) \\
\hline
\end{tabular}


72 Body-Part Morphemes in Matis (Panoan)

\begin{tabular}{|c|c|c|}
\hline \multirow{3}{*}{ kui- } & kuişak & jaw \\
\hline & kuişakete & beard \\
\hline & kuitonko & chin \\
\hline \multirow{3}{*}{ kui- } & kui & vagina \\
\hline & kui iksak & vaginal lips \\
\hline & kui tsitami & perineum \\
\hline \multirow{5}{*}{ ma- } & mapais & horn \\
\hline & mapi & brain \\
\hline & maşatkete & hair \\
\hline & maşo & head \\
\hline & maşo kaşuku/tsitsu & back of head \\
\hline \multirow{12}{*}{$\mathrm{mi-}$} & mikin & hand \\
\hline & mikin ana & palm \\
\hline & mikin kaşuku & dorsum of hand \\
\hline & mikin maşopa & thumb \\
\hline & mikin risan/ris $\beta u$ & fingertip \\
\hline & mikin titun & wrist \\
\hline & mikin titun kasuku & dorsum of wrist \\
\hline & mintsin $\beta$ urus & elbow \\
\hline & mintsis & fingernail, claw \\
\hline & mipuku & anterior forearm region \\
\hline & mipuku kaşuku & posterior forearm region \\
\hline & mirantakua & anterior cubital region \\
\hline mik- & mikas & rib \\
\hline nak- & naktete & waist \\
\hline
\end{tabular}




\begin{tabular}{|c|c|c|}
\hline nik- & niktşun & navel \\
\hline pa- & paßisan & ear \\
\hline \multirow{4}{*}{ pi- } & pii & wing, feather \\
\hline & pişoro & shoulder \\
\hline & pişuku & armpit \\
\hline & pitiska & upper arm, paw \\
\hline \multirow{2}{*}{ po- } & poßik & belly skin \\
\hline & popes & lateral part of the abdomen \\
\hline \multirow{6}{*}{ pu- } & pui kini & anus \\
\hline & puku & belly \\
\hline & puku tsirik & large intestine \\
\hline & puku tşunu & small intestine \\
\hline & purunte & thigh \\
\hline & pusa & stomach \\
\hline \multirow{2}{*}{ sa- } & saßet & hip \\
\hline & saes & groin \\
\hline sik- & siktun, siktoro & thorax \\
\hline $\mathrm{si}^{\dot{-}}$ & sita & tooth \\
\hline \multirow{6}{*}{ su- } & sui & penis \\
\hline & sui $\beta$ ikik & clitoris \\
\hline & sui maßit & foreskin \\
\hline & sui maşo & glans \\
\hline & sui rişan & urethra \\
\hline & suma & breast, nipple, milk \\
\hline ra- & rara & body \\
\hline
\end{tabular}


74 Body-Part Morphemes in Matis (Panoan)

\begin{tabular}{|c|c|c|}
\hline \multirow{2}{*}{ ran- } & ranßíru & knee \\
\hline & rantakua & behind the knee \\
\hline \multirow{4}{*}{ rí- } & rimurun & nasal cavity \\
\hline & rişan & nose, beak, snout \\
\hline & rişan kaşuku & nasal bridge \\
\hline & rişan kini & nostril \\
\hline \multirow{8}{*}{ ta- } & tai & foot \\
\hline & tai ana & sole \\
\hline & tai kaşuku & dorsum of foot \\
\hline & tai masopa & big toe \\
\hline & tai rişan/riş $\beta u$ & tiptoe \\
\hline & tai titun & ankle \\
\hline & tai tsituku & heel \\
\hline & tantis & toenail \\
\hline tak- & takua & liver \\
\hline $\tan -$ & tanpes & cheek \\
\hline \multirow{6}{*}{$\mathrm{ti}-$} & ti $\beta$ ik & neck skin \\
\hline & tios & uvula \\
\hline & tispan & neck base \\
\hline & titun & neck \\
\hline & titun kaşuku & nape \\
\hline & tiwispo, titun wispo & cervical spine \\
\hline \multirow{3}{*}{ tsi- } & tsißin & leg \\
\hline & tsipuis & rectum \\
\hline & tsitsu & ass \\
\hline
\end{tabular}




\begin{tabular}{|c|c|c|}
\hline \multirow{4}{*}{$\mathrm{u}-$} & ubu & scrotum \\
\cline { 2 - 3 } & ubu işi & testicles \\
\hline \multirow{4}{*}{ wi- } & wipuku & lower part of the leg \\
\cline { 2 - 3 } & wipuku titun & ankle \\
\cline { 2 - 3 } & wipuku wispo & shin \\
\cline { 2 - 3 } & wipuku wisuku & calf \\
\hline
\end{tabular}

In addition to the syllable structure ' $\mathrm{C}$ (onsonant) $\mathrm{V}$ (owel)' of most body-part prefixes in the Matis language, some of these bound morphemes also have the following syllable patterns: $(\mathrm{V}-),\{\mathrm{u}-\}$ 'testicles'; (VC-), \{an- $\}$ 'tongue', \{ik- $\}$ 'lips/mouth'; and (CVC-), $\{\tan -\}$ 'cheek', \{nik-\} 'belly button'. Having just one prefix slot in lexical bases, the basic function of prefixation in the Matis language is to indicate the participant's body-part that receives the action or process conveyed by the verb. For example, the following clause has the transitive verb remisikak, which contains the prefix $\left\{\mathrm{ri}^{-}\right\}$'nose', and whose body-part possessor corresponds to the absolutive argument, $\beta a k u \dot{~ ' c h i l d ' ? ~}$

3 The following category label abbreviations, mostly based on the Leipzig Glossing Rules, are used throughout this paper: 1, first person; 2, second person; 4, fourth person; A, agente-like argument of canonical transitive verb; ABS, absolutive; AG, agent; AGR, agreement; ANT, anterior; DECL, declarative; DES, desiderative; EMP, emphatic; ERG, ergative; FOC, focus; ID, identity; INC, inconclusive; INTR, intransitive; INV, involuntary; INTS, intensity; LOC, locative; NID, non-identity; NMLZ, nominalizer; O, patient-like argument of canonical transitive verb; PST, past; REC, recent; S, single-argument of canonical intransitive verb; SG, singular; SIM, simultaneous; TOT, totality; TR, transitive; >, switch-reference (marked clause $>$ reference clause). 

(1) inbi $\quad \beta a k u i-\varnothing \quad$ ri-sik-a-k
1SG.ERG child-ABS nose-wash-REC.PST-DECL
'I washed the child's nose.'

Just like some Panoan languages, such as Matses (Fleck 2006) and Kashibo-Kakataibo (Zariquiey \& Fleck 2012), the Matis language lexis also has polysyllabic nominal morphemes, whose first syllable is generally similar to that of the prefixes. However, in both texts and elicited clauses collected in fieldwork, the polysyllabic nouns are less frequent than monosyllabic prefixes. The following example presents the prefix \{pi-\} 'paw', attached to the verb pibikeakitak, and also the corresponding noun pitiska 'paw'.

$\begin{array}{llc}\begin{array}{l}\text { kuen=ek } \\ \text { leave=NID.SIM.A/S }>\text { S }\end{array} & \text { pitiska } & \text { ami-rapa } \\ \text { ikek-ek } & \text { paw } & \text { big-EMP } \\ \text { like.that-INTR.AGR } & \text { swell.up=ID.SIM.A/S }>S \\ \text { pi-ßikeakit-a-k } & \text { kuaka-kit } & \text { ina } \\ \text { paw-turn-REC.PST-DECL } & \text { hear-AG.NMLZ that }\end{array}$

'(With the anteater) going with very large paws swelling up like that, that we heard that that one turned its paws.'

The possessor of the body part 'paw' corresponds to the referent sai 'anteater' (bitten on the paw by the jaguar, according to the context of the narrative). In this example, the verb phrase pißikeakitak is composed of the prefix $\left\{\mathrm{pi}^{-}\right\}$'paw', whereas the noun phrase pitiska amirapa contains the noun pitiska 'paw'. Moreover, while adjectives denoting quality, such as amirapa 'big', are preceded by the polysyllabic noun, adjectives denoting colours, as shown in the following example, receive prefixes. 
(3)

$\begin{array}{ll}\text { tşofe } & \boldsymbol{\beta i} \text { - } \text { jin } \\ \text { capuchin.monkey } & \text { face-orange }\end{array}$

'The capuchin monkeys are the ones in orange-face.'

(Ferreira, R. 2005: my analysis and translation)

Thus, besides verbal prefixation, body-part prefixes are also attached to colour adjectives, that correspond, therefore, to nonverbal predicates. To summarize, synthetic constructions are characterized by monosyllabic prefixes, which are attached to action verbs (forming verbal predication) and also to colour adjectives (nonverbal predication). By contrast, analytical constructions are characterized by polysyllabic nominal morphemes, accompanied by adjectival items denoting quality.

\subsection{Prefixation and Verbal Reduplication}

Reduplication is a worldwide phenomena, with a variety of functional and derivational cross-linguistic tendencies (Rubino 2005, Tak 2007). In the Matis language, reduplication conveys grammatical functions of intensity or totality, processing from the left of the base, with the root reduplicant in the initial position. In addition to this type of root reduplication, the grammar of this language also processes verbal stem reduplication, together with prefixes referring to body parts. In the following clause, for example, it is presented complex stem reduplication (pimos $\sim$ it-mos), and the simple root reduplication (nokos nokos). 


$$
\begin{aligned}
& \text { niktope }=\text { kin } \quad \mathrm{a} \beta \mathrm{i} \quad \text { pimos } \sim \text { pi-mos } \\
& \text { get.up=ID.SIM.A/S }>\text { A 4SG.ABS TOT } \sim \text { paw-bite } \\
& \text { kepe=kin nokos } \sim \text { nokos } \\
& \text { say }=\text { ID.SIM.A/S }>\text { A INTS roar }
\end{aligned}
$$

This example presents the verbal root mos 'bite' to which the prefix $\{\mathrm{pi}-\}$ 'paw' is attached, resulting in the base stem pimos 'bite the paw'. Then the stem is reduplicated to the left of the base, pimospimos 'bit it at the whole paws', to express the totality meaning conveyed by the verb, which affects the possessor of the body part. In other words, this verbal item means that the bite (of the jaguar) affected both paws of the anteater, as the verbal root is reduplicated along with the prefix referring to that body part.

Moreover, in this example, the noun phrase nokosnokos 'roar hard' has the onomatopoeic form nokos, which is, in the Matis language, usually reduplicated to indicate intensity. In this language, in addition to the intensity meaning conveyed by nominal reduplications, verbal roots are also reduplicated in order to express intensity and/or totality, such as kuankuane 'all quickly go away' and nanane 'all really die'. Therefore, depending on the context related to the meaning of the full stem reduplication of action verbs, intensity and/or totality functions can be applied to the body-part prefix attached to the verb root.

\subsection{Syntactic Tracking of Body-Part Reference}

The basic position of the body-part possessor in the Matis prefixation constructions is immediately to the left of the verb. In spite of this syntactic position, in the complex clauses from narratives, the possessor noun phrase, which is in absolutive function, might not be 
necessarily placed immediately to the left of the verb. As presented in the following clause, the relation of the possessor argument kamunrapa 'jaguar' to the prefix $\{\beta \dot{\mathrm{i}}-\}$ 'face' is established by means of the participant agreement of the Matis switch-reference system.

\begin{tabular}{|c|c|c|}
\hline kamun-rapa & tşo $=$ kin & i $\beta \mathrm{i}$ \\
\hline jaguar-EMP & come $=$ ID.SIM.A/S $>$ A & 1SG.ABS \\
\hline bet-nu & kape $=\mathbf{s o}$ & $\operatorname{in} \beta \mathrm{i}$ \\
\hline catch-DES & $\operatorname{try}=\mathrm{NID} \cdot \mathrm{SIM} . \mathrm{A} / \mathrm{S}>\mathrm{O}$ & 1SG.ERG \\
\hline tonkate & $\boldsymbol{\beta} \mathbf{i}-$ sananpa=ak & tonkate \\
\hline shotgun & face-aim=NID.ANT.O $>$ A/S & shotgun \\
\hline se-tanpe $=e k$ & pakit-tanpe $=\mathrm{ek}$ & \\
\hline hit-?=ID.SIM. & jump-?=ID.SIM.A & $\mathrm{A} / \mathrm{S}>\mathrm{S}$ \\
\hline
\end{tabular}

The switch-reference marker $\{=\mathrm{kin}\}$, attached to the verb stem tsokin 'came', conveys the coreferentiality function of the subject kamunrapa 'jaguar' to the following transitive clause subject. In this clause, the verb stem kapeso 'trying', which receives the switchreference marker $\{=\mathrm{So}\}$, indicates that the referent of this subject is the same of the direct object of the next clause. That is to say, the referent kamunrapa 'jaguar' is retrieved as a null absolutive argument of the verb stem Bisananpak 'to aim at the face', owing to the interaction of body-part morphemes with the switch-reference system. The following example presents the clause-chaining relation of the possessor sairapa 'anteater' with its body part $\{\mathrm{pi}-\}$ 'paw'. 
(6)

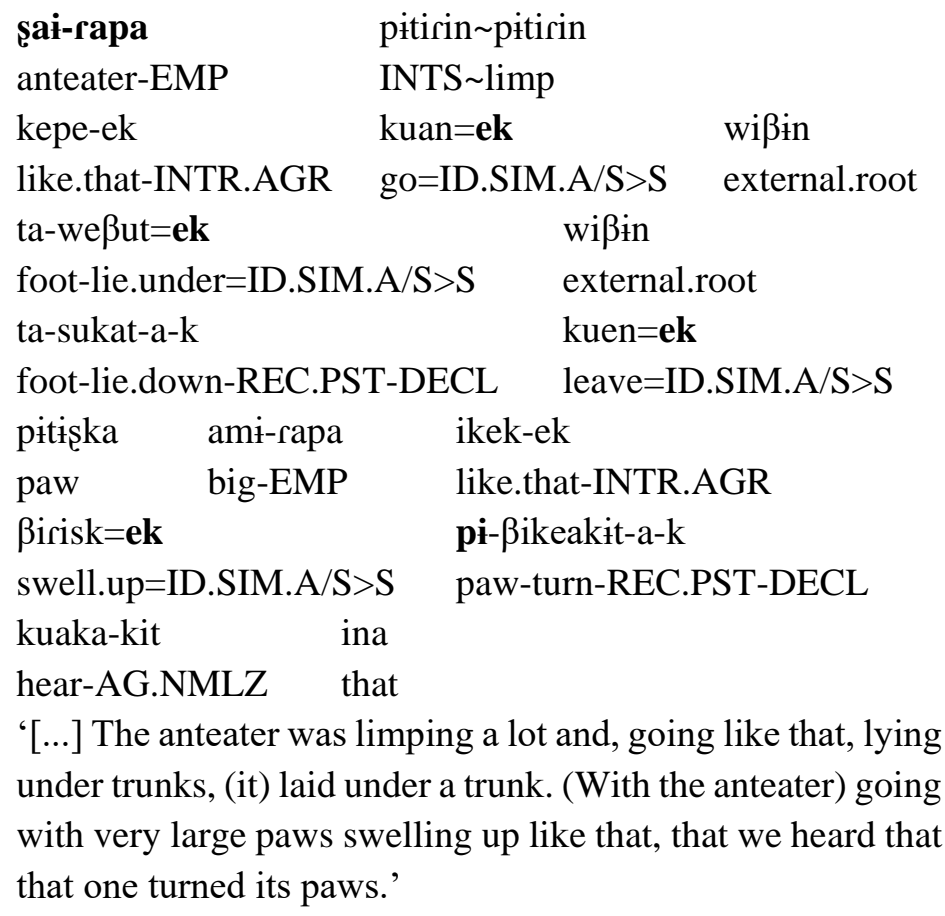

In this example, the switch-reference marker $\{=\mathrm{ek}\}$ which indicate the participant agreement function on a simultaneous verbal event, establish the relation of the participant sairapa 'anteater' as the possessor of the body part $\left\{\mathrm{pi}^{-}\right\}$'paw'. In this clause complex, every verb that receives the marker $\{=\mathrm{ek}\}$ retrieves the absolutive argument sairapa 'anteater' up to the body-part predicate pißikeakitak 'turned the paw'. To sum up, analyses of narratives indicate that the relation of body part and its possessor, in clause-chaining construction, is established on referential progression by means of the participant agreement in switch-reference system.

Despite applicative-like function of body-part terms in Matses 
(Fleck 2006), with the addition of an extra absolutive participant, it is not the case for the Matis language since it lacks clear grammatical evidence for body-part applicative voice. Moreover, as the Matis language is basically an ergative-absolutive language, the possessor noun-phrase is generally the absolutive argument. However, in clauses whose subject or direct object corresponds to second-person plural pronoun, which exclusively follows the nominative-accusative pattern, the possessor noun phrase is in accusative or nominative case.

\section{Semantic and Discursive Context of Body Parts in Matis}

The description of the examples from narratives is based on contextual analysis of the meaningful lexical choices made by the narrator. In this sense, following the principles of systemic functional grammar proposed by Halliday \& Matthiessen (2014), the semantic and pragmatic level of analysis about the discursive usage of body-part morphemes demonstrates the coding of experience and interpersonal relationships into linguistic meaning.

\subsection{Semantic Extension from Basic Body-Part Meanings}

Verbal prefixes of the Matis language are also used to convey abstract locative meanings. In this type of construction, the spatial meanings are based on the semantic extension of the basic meanings expressed by the monosyllabic body-part prefixes. As an illustration of the body-part prefixes abstraction, Table 2 presents a set of these prefixes, the basic meanings and its semantic extensions. 
82 Body-Part Morphemes in Matis (Panoan)

Table 2. Semantic Extension of Body-Parts Prefixes in the Matis Language

\begin{tabular}{|c|c|c|}
\hline Prefixes & Basic Meanings & Spatial Meanings \\
\hline an- & tongue & internal part \\
\hline ra- & body & external part \\
\hline ri- & nose & front part \\
\hline ka- & back & back part \\
\hline ma- & head & upper part \\
\hline ta- & foot & lower part \\
\hline pa- & ear & lateral part \\
\hline \multicolumn{2}{|r}{} \\
\hline
\end{tabular}

The extended meanings of these body-part prefixes, which convey metaphorical spatial notions, are related to inanimate possessors. This semantic process distinguishes the reference value of the spatial meanings in comparison to the basic meanings, that are related to animated possessors. That is, the literal meanings, referring to body parts of human and nonhuman animals, are semantically extended in order to express parts of objects and plants. The following clauses with the metaphorical meaning of the body-part prefixes $\{a n-\}$ 'tongue' and \{ra- $\}$ 'body' are examples of this type of process.

$$
\begin{array}{lll}
\text { maurona }=\mathrm{n} & \text { iwi } & \text { an-pe-a-k } \\
\text { maurona }=\mathrm{ERG} & \text { tree } & \text { tongue-eat-REC.PST-RECL }
\end{array}
$$
'Termite (a wood-eating worm) ate the stem's core.'

$$
\begin{aligned}
& \text { maurona }=\mathrm{n} \quad \text { iwi ra-pe-a-k } \\
& \text { maurona=ERG tree body-eat-REC.PST-RECL } \\
& \text { 'Termite (a wood-eating worm) ate the stem's bark.' }
\end{aligned}
$$


Metaphorical meaning, unlike literal references of body-part prefixes, refer to abstract spatial relationships, whose possessors correspond to inanimate referents (parts of objects, tawa 'arrow'; and entities of nature, wißin 'root.external', for example). Thus, in verbal constructions involving prefixation, if the complement (possessor) of the verb is inanimate, the meaning of these prefixes conveys abstract spatial relations, as illustrated in the following example with the bodypart prefix $\{$ ta- $\}$ 'foot'.

\begin{tabular}{|c|c|}
\hline sai-rapa & piticin piticin \\
\hline anteater-EMP & INTS limp \\
\hline kepe-ek & kuan=ek \\
\hline like.that-INTR.AGR & go $=$ ID.SIM.A $/ S>S$ \\
\hline wißin & ta-we $\beta u t=e k$ \\
\hline external.root & foot-lie.under=ID.SIM.A/S $>S$ \\
\hline wißin & at-a-k \\
\hline external.root foot- 1 & e.down-REC.PST-DECL \\
\hline
\end{tabular}

In addition to the concrete meanings of the Matis body-part prefixes, the semantic level of this language can process abstract extensions from the basic references of these items. Thus, I propose that besides the functional value of the inanimate reference of the possessor, the metaphorical conceptual system, according to the principles of metaphorical representation in Lakoff \& Johnson (1980), is the cognitive condition for the semantic processing of extension and expression of wider spatial references from basic meanings. 


\subsection{Pragmatic Information of Body-Part Morphemes}

In the Matis language, verb stems, to which body-part prefixes are attached, may be preceded by the noun of the corresponding body part, whose form of the first syllable is usually the same of the prefix. Such a construction that indicates the emphatic function of the body-part noun is illustrated in the following example, in which the verb stem rimiraktsakan, bearing the body-part prefix $\{\mathrm{ri}-\}$ 'snout', is preceded by the body-part noun itemixan 'snout'.
$(10)$

\begin{tabular}{llll} 
mitsi & mibi & \multicolumn{1}{c}{ ro $\beta=n$} & tintema \\
where & 2SG.ABS & human=ERG & hit \\
rişan & ri-mirak-tsakan & wiktanpe-kin \\
snout & snout-point-INC.INV & quickly-TR.AGR
\end{tabular}
'(The jaguar asked:) "Where does the human hit you?" (And the anteater) pointing quickly near the snout [...].'

In this example, the co-occurrence of body-part morphemes, with the polysyllabic body-part noun risan, followed by the prefixed verb stem rimiraktsakan 'pointing quickly near the snout', indicates the prominence of the information related to the body part 'snout'. According to the basic notions of information structure (Krifka 2007), the emphatic interpretation given to the polysyllabic body-part noun represents unexpected information in the narrative discourse, which express the focus function of this reference.

Polysyllabic body-part nouns may also precede prefixed verbs if the speaker intends to focus the body-part reference in relation to the

\footnotetext{
4 In this example from a narrative, the possessor of the body part 'snout' is the referent s $a \dot{i}$ 'anteater' (indicated in the translation between parentheses), that was introduced earlier in the narrative.
} 
meaning of the prefix. For example, the verbal construction miwisuwaek means 'smearing the hand and/or the forearm', since the meaning of the prefix $\left\{\mathrm{mi}^{-}\right\}$corresponds to both of the body parts (see Table 1). Thus, considering the specification of only one of these body-part references, either mikin miwisuwaek 'smearing the hand' or mipuku miwisuwaek 'smearing the forearm' verbal construction can be used respectively. In addition to focus, the following clause shows that body-part terms can also be used as topic.
(11)

$\begin{array}{llll}\text { pitiska } & \text { kimo } \quad \text { ni } & \text { ni=n } \\ \text { paw } & \text { right } & \text { here } & \text { here=LOC } \\ \text { гоßo=n } & \text { tintema-e-k } & \\ \text { human=ERG } & \text { hit-NPST.DECL }\end{array}$
'[...] (The anteater said:) "Right here on the paw, human hits (me) here".'

In the Matis language, "there are variations [in word order] that are conditioned by pragmatic reasons, [so] when the object moves to the beginning of the clause, there is a topicalization". 5 (Ferreira, R. 2005). Hence, in the previous example, the (anteater) reported speech has the polysyllabic noun pitixka 'paw' at the beginning of the clause, which characterizes it as a topic, considering that this body part corresponds to "[...] the common knowledge [that] will be enriched by a new proposition" (Matić et al. 2014).

The present functional description about body-part morphemes in the Matis language is part of a wider research project of narrative study about the functional interaction of reference mechanisms and transitivity systems. This project also aims to describe the semantic

\footnotetext{
${ }^{5}$ On original: "Existem variações que estão condicionadas por razões pragmáticas, quando o objeto se move para o início da sentença, há uma topicalização".
} 
and pragmatic conditions for those systems, and future studies have to be done about the discourse topic based on cognitive-pragmatic approach (van Dijk 1977, Chang 2007). In doing so, the results of these researches will provide a deeper knowledge about the systematic relation of transitivity systems in the Matis language with text and context, that can be used for didactic education and cultural documentation purposes.

\section{Conclusion}

Body-part morphemes in the Matis language are structured in synthetic constructions as monosyllabic prefixes and, less frequently, in analytical constructions as polysyllabic nominal items. As polysyllabic morphemes, these items are adjacent to adjectives of quality. Moreover, prefixed verb stems can be preceded by similar body-part noun to perform focus function, and polysyllabic nouns can also express topic function if structured at the beginning of the clause.

The body-part prefixes are attached to action verbs to construct verbal predications, and also to colour adjectives to construct nonverbal predications. On verb stems, the basic meaning of body parts, that is related to animate possessors, is extended to more generalized spatial meanings related to inanimate possessors. Additionally, verbal reduplication processes involving body-part prefixes include the meaning of the prefix attached to the verb. In clause-chaining constructions, the relation of body part and its possessor is established on referential progression by means of the participant agreement in switch-reference system.

Since the prefixation of body-part items is likely a process of every Panoan languages, references to inanimate possessors, and the 
meaning extensions of some of these prefixes, as well as its pragmatic usage as topic and focus, may be properties of all or most languages of the linguistic family. To conclude, both synchronic (communicative functions) and diachronic (historical developments) aspects of bodypart morphemes in narratives and other textual sources indicate the descriptive and typological relevance of this theme in the Matis language, as well as in the Panoan family.

\section{References}

Aikhenvald, A. 2007. Typological Distinctions in Word-Formation. In

S. Timothy (ed.), Grammatical Categories and the Lexicon 1-65. Cambridge: CUP.

Arisi, B. 2007. Matis e Korubo: Contato E Índios Isolados No Vale Do Javari, Amazônia. M.A. Thesis, Federal University of Santa Catarina.

Arisi, B. 2011. A Dádiva, a Sovinice e a Beleza: Economia Da Cultura Matis, Vale do Javari, Amazônia. Ph.D. Dissertation, Federal University of Santa Catarina.

Arisi, B. 2012. La No-Frontera Pano: Etnónimos Como Categorías Alternativas Y Múltiples Entre Matis y Korubo. Tipití: Journal of the Society for the Anthropology of Lowland South America 10.1, 19-36.

Arisi, B. \& F. Milanez. 2017. Isolados e Ilhados: Indigenismo e Conflitos No Vale Do Javari, Amazônia. Estudos IberoAmericanos 43.1, 49-66.

Barbosa, R. 2012. Aspectos Tipológicos Na Formação De Palavras Em Um Grupo De Línguas Da Família Pano. M.A. Thesis, Univesity of Campinas. 
Barbosa, R. 2014. Construções Simples e Complexas nas Reduplicações Lexicais de um Grupo de Línguas Pano: Uma Breve Caracterização De Sua Iconicidade Derivacional. Revista Estudos Linguísticos 43.1, 272-285.

Barbosa, R. 2018. Gramaticalização do Sincretismo de Casos em Linguas da Família Pano. Muenchen: Lincom.

Barbosa, R. 2020. Alinhamento Morfossintático Em Matis (Pano). LIAMES: Linguas Indigenas Americanas 20, e020017.

Barbosa, R. n.d.a. Aspects of Switch-Reference in Matis (Panoan). Unpublished manuscript.

Barbosa, R. et al. n.d.b. Sistema Consonantal em Matis (Pano): Variação e Estatuto Fonológico das Plosivas Sonoras. Unpublished manuscript.

Chang, V. 2007. A Cognitive-Pragmatic Approach to Discourse Topic:

A Cross-Linguistic Analysis and Universal Account. Journal of Universal Language 8.1, 1-27.

de La Grasserie, R. 1889. De La Famille Linguistique Pano. Actas del

VII Congreso Internacional de Americanistas 438-450. Paris:

Maisonneuve.

Ferreira, R. 2001. Língua matis (Pano): Aspectos Descritivos Da Morfossintaxe. M.A. Thesis, University of Campinas.

Ferreira, R. 2005. Língua Matis (Pano): Uma Descrição Gramatical. Ph.D. Dissertation, University of Campinas.

Ferreira, R. 2012. Aspectos Tipológicos Do Switch-Reference Em Línguas Da Família Pano. In E. de Souza (ed.), Funcionalismo Linguístico: Análise e Descrição 197-224. São Paulo: Contexto.

Ferreira, R. 2017. Concordância De Participante Em Matis (Pano). Amérindia 39, 381-406.

Ferreira, V. 2000. Língua Matis (Pano): Uma Análise Fonológica. M.A. Thesis, University of Campinas. 
Ferreira, V. 2005. Estudo Lexical da Língua Matis: Subsídios para um Dicionário Bilíngue. Ph.D. Dissertation, University of Campinas. Fleck, D. 2013. Panoan Language and Linguistics. Anthropological Papers of the American Museum of Natural History 99. New York: American Museum of Natural History.

Halliday, M. \& C. Matthiessen. 2014. Halliday's Introduction to Functional Grammar. 4th edition. London: Arnold.

Instituto Sócio Ambiental. 2014. Povos Indígenas No Brasil.

Available at $<$ https://pib.socioambiental.org/pt/povo/matis $>$.

Krifka, M. 2007. Basic Notions of Information Structure. Acta Linguistica Hungarica 55.3-4, 243-276.

Lakoff, G. \& M. Johnson. 1980. Metaphors We Live By. London: The University of Chicago Press.

Lanes, E. 2005. Aspectos da Mudança Lingüística em um Conjunto de Línguas Amazônicas: As línguas Pano. Ph.D. Dissertation, Federal University of Rio de Janeiro.

Loos, E. 1999. Pano. In R. Dixon \& A. Aikhenvald (eds.), The Amazonian Languages 227-250. Cambridge: CUP.

Matić, D. et al. 2014. Information Structure and Reference Tracking in Complex Sentences: An Overview. In R. van Gijn et al. (eds.), Information Structure and Reference Tracking in Complex Sentences 1-42. Amsterdam: John Benjamins.

Ribeiro, L. 2006. Uma Proposta De Classificação Interna Das Línguas Da Família Pano. Revista Investigações. Lingüistica e Teoria Literária 19.2, 157-182.

Ribeiro, L. \& G. Cândido. 2008. A Formação De Palavras a Partir De Morfemas Monossilábicos Nominais e Bases Verbais Em línguas Indígenas Da Família Pano: Prefixação Ou Incorporação Nominal? Veredas 12.1, 129-145.

Rodríguez, C. 2017. Prefixos De Partes Del Cuerpo En La Lengua 
90 Body-Part Morphemes in Matis (Panoan)

Iskonawa. Liames 17.1, 117-141.

Rubino, C. 2005. Reduplication: Form, Function and Distribution. In

B. Hurch (ed.), Studies on Reduplication. Berlin: Mouton de Gruyter.

Tak, J. 2007. Three Cross-Linguistic Tendencies in Reduplication Revised. Journal of Universal Language 8.2, 105-122.

van Dijk, T. 1977. Text and Context: Explorations in the Semantics and Pragmatics of Discourse 261. London: Longman.

van Gijn, R. 2016. Switch Reference: An Overview. In R. van Gijn \& J. Hammond (eds.), Switch Reference 2.0 1-53. Amsterdam: John Benjamins.

Zariquiey, R. \& D. Fleck. 2012. Body-Part Prefixation in KashiboKakataibo: Synchronic or Diachronic Derivation? International Journal of American Linguistics 78.3, 385-409. 